\title{
Metabolic regulation of "Ca. Methylacidiphilum fumariolicum" SolV cells grown under different nitrogen and oxygen limitations
}

\author{
Ahmad F. Khadem, Arjan Pol, Adam S. Wieczorek, Mike S. M. Jetten and Huub J. M. Op den Camp*
}

Department of Microbiology, Institute of Water and Wetland Research, Radboud University Nijmegen, Nijmegen, Netherlands

\section{Edited by:}

Naomi L. Ward, University of

Wyoming, USA

Reviewed by:

Lisa Y. Stein, University of Alberta, Canada

Peter Dunfield, University of Calgary, Canada

Colin Murrell, University of East

Anglia, UK

*Correspondence:

Huub J. M. Op den Camp,

Department of Microbiology, Institute of Water and Wetland Research,

Radboud University Nijmegen,

Heyendaalseweg 135, NL-6525 AJ,

Nijmegen, Netherlands.

e-mail: h.opdencamp@science.ru.nl
Aerobic methanotrophic bacteria can use methane as their sole energy source. The discovery of "Ca. Methylacidiphilum fumariolicum" strain SolV and other verrucomicrobial methanotrophs has revealed that the ability of bacteria to oxidize $\mathrm{CH}_{4}$ is much more diverse than has previously been assumed in terms of ecology, phylogeny, and physiology. A remarkable characteristic of the methane-oxidizing Verrucomicrobia is their extremely acidophilic phenotype, growing even below pH 1. In this study we used RNA-Seq to analyze the metabolic regulation of "Ca. M. fumariolicum" SolV cells growing at $\mu_{\max }$ in batch culture or under nitrogen fixing or oxygen limited conditions in chemostats, all at $\mathrm{pH} 2$. The analysis showed that two of the three pmoCAB operons each encoding particulate methane monoxygenases were differentially expressed, probably regulated by the available oxygen. The hydrogen produced during $\mathrm{N}_{2}$ fixation is apparently recycled as demonstrated by the upregulation of the genes encoding a Ni/Fe-dependent hydrogenase. These hydrogenase genes were also upregulated under low oxygen conditions. Handling of nitrosative stress was shown by the expression of the nitric oxide reductase encoding genes nor $\mathrm{B}$ and nor $\mathrm{C}$ under all conditions tested, the upregulation of nitrite reductase nirK under oxygen limitation and of hydroxylamine oxidoreductase hao in the presence of ammonium. Unraveling the gene regulation of carbon and nitrogen metabolism helps to understand the underlying physiological adaptations of strain SolV in view of the harsh conditions of its natural ecosystem.

Keywords: Methylacidiphilum, methane, RNA-Seq, Verrucomicrobia, metabolic regulation, nitrogen, pMMO

\section{INTRODUCTION}

Methanotrophs are an unique group of microorganisms that can use methane $\left(\mathrm{CH}_{4}\right)$ as sole carbon and energy source (Hanson and Hanson, 1996). Methanotrophs are found both in aerobic and anaerobic natural environments (Hanson and Hanson, 1996; Boetius et al., 2000; Raghoebarsing et al., 2006; Conrad, 2009). Aerobic methane-oxidizing bacteria are represented by members of the Alphaproteobacteria, the Gammaproteobacteria, the Verrucomicrobia, and the NC10 phylum (Hanson and Hanson, 1996; Op den Camp et al., 2009; Ettwig et al., 2010). "Candidatus Methylomirabilis oxyfera," a representative of the latter phylum and growing anaerobically in the absence of oxygen, has the unique ability to produce intracellular oxygen through an alternative denitrification pathway (Ettwig et al., 2010).

During aerobic $\mathrm{CH}_{4}$ oxidation, energy is conserved during the oxidation of methanol, formaldehyde, and formate (Hanson and Hanson, 1996; Chistoserdova et al., 2009). In the oxidation of methanol, electrons are transferred to a membrane bound electron transport chain via a pyrroloquinoline quinone cofactor to cytochrome $c$ and the bcl complex by the enzyme methanol dehydrogenase. During formaldehyde and formate oxidation, NAD is reduced to $\mathrm{NADH}$ and transferred to $\mathrm{NADH}$-oxidoreductase complex I (nuo genes). Electrons flow via the membrane protein complexes, Nuo, bc1, to the cytochrome $c$ oxidases and produce a proton motive force that is converted to the cellular energy carrier ATP by the ATPase enzyme complex.

Verrucomicrobial methanotrophs were isolated from volcanic areas in Italy, New Zealand, and Russia (Dunfield et al., 2007; Pol et al., 2007; Islam et al., 2008) and, the genus name "Methylacidiphilum" was proposed since 16S rRNA gene sequences of the three independent isolates had $98-99 \%$ sequence identity (Op den Camp et al., 2009). Although environmental clone libraries from many ecosystems show a large abundance and biodiversity of Verrucomicrobia (Wagner and Horn, 2006), little is known about their in situ physiology. There are now several verrucomicrobial genome assemblies available (van Passel et al., 2011) including two of the verrucomicrobial methanotrophs (Hou et al., 2008; Khadem et al., 2012). The genome data of strains V4 and SolV showed some similarities but also major differences in the C1-utilization pathways compared to proteobacterial and NC10 methanotrophs. The functional significance of these differences can only be validated by a combination of physiological and expression studies.

Physiological studies of “Ca. M. fumariolicum" strain SolV have demonstrated that this microorganism was able to grow with ammonium, nitrate, or dinitrogen gas as nitrogen source (Pol et al., 2007; Khadem et al., 2010). ${ }^{13}$ C-labeling studies showed that strain 
SolV growing on $\mathrm{CH}_{4}$, fixed $\mathrm{CO}_{2}$ into biomass exclusively via the Calvin Benson Bassham (CBB) cycle (Khadem et al., 2011). Based on these results we expect that genes involved in nitrogen fixation are only expressed in the absence of ammonium/nitrate and genes involved in the CBB cycle are constitutively expressed. To evaluate this in more detail, analysis of the complete set of transcripts (the transcriptome) and their quantity present in cells grown under different condition is needed.

With the development of microarrays (Malone and Oliver, 2011) high-throughput quantification of the transcriptome became possible, improving the low throughput mRNA data from Northern blots or reverse-transcription PCR (RT-PCR) analysis. More recently, next generation sequencing has been shown to be a very powerful method to analyze the transcriptome of cells by what is known as RNA-Seq (Wang et al., 2009). Furthermore, this technique can detect transcripts without corresponding genomic sequences and can detect very low abundance transcripts (Croucher and Thomson, 2010; Malone and Oliver, 2011).

In this study we used RNA-Seq to analyze the genome wide transcriptome of "Ca. M. fumariolicum" SolV cells grown under different conditions at $\mathrm{pH}$ 2. Expression profiles of exponentially growing SolV batch cultures (at $\mu_{\max }$ ) were compared to nitrogen fixing or oxygen limited chemostat cultures and used to unravel the gene and genome regulation of carbon and nitrogen metabolism which may reflect the underlying physiological adaptations of SolV.

\section{MATERIALS AND METHODS}

\section{ORGANISM AND MEDIUM COMPOSITION FOR GROWTH}

"Ca. Methylacidiphilum fumariolicum" strain SolV used in this study was originally isolated from the Solfatara volcano, Campi Flegrei, near Naples, Italy (Pol et al., 2007).

Preparation and composition of the growth medium $(\mathrm{pH} 2)$ was described previously (Khadem et al., 2010). Mineral salts composition and concentration were changed for oxygen limited SolV chemostat cultures: $0.041 \mathrm{gl}^{-1} \mathrm{MgCl}_{2} \cdot 6 \mathrm{H}_{2} \mathrm{O}$ was added (instead of $0.08 \mathrm{gl}^{-1}$ ) and $\mathrm{CaHPO}_{4} \cdot 2 \mathrm{H}_{2} \mathrm{O}$ was replaced by $0.138 \mathrm{gl}^{-1}$ $\mathrm{NaH}_{2} \mathrm{PO}_{4} \cdot \mathrm{H}_{2} \mathrm{O}$ to limit precipitation.

\section{CHEMOSTAT CULTIVATION}

Chemostat cultivation of strain SolV under nitrogen fixing condition at pH 2 was performed as described previously (Khadem et al., 2010). Growth yield and stoichiometry of $\mathrm{CH}_{4}$ conversion to $\mathrm{CO}_{2}$ of strain SolV were also determined for oxygen limited SolV chemostat cultures. The chemostat liquid volume was $300 \mathrm{ml}$ and the system was operated at $55^{\circ} \mathrm{C}$ with stirring at $900 \mathrm{rpm}$ with a stirrer bar. The chemostat was supplied with medium at a flow rate of $5.1 \mathrm{mlh}^{-1}$, using a peristaltic pump. Culture liquid level was controlled by a peristaltic pump actuated by a level sensor. A gas mixture containing (v/v) $5.8 \% \mathrm{CH}_{4}, 2.3 \% \mathrm{O}_{2}, 0.4 \% \mathrm{~N}_{2}$, and $91.1 \% \mathrm{CO}_{2}$ was supplied to the chemostat by mass flow controllers through a sterile filter and sparged into the medium just above the stirrer bar. Oxygen concentrations in the liquid were measured with a Clarke-type electrode.

After steady state was reached, $\mathrm{CH}_{4}$ and $\mathrm{O}_{2}$ consumption and $\mathrm{CO}_{2}$ production were determined by measuring the ingoing and outgoing gas flows and the gas concentrations. The outgoing gas passed through a sterile filter at a flow rate of $11.9 \mathrm{ml} \mathrm{h}^{-1}$, and contained (v/v) a mixture of approximately $4.8 \% \mathrm{CH}_{4}, 0.72 \% \mathrm{O}_{2}$, $0.7 \% \mathrm{~N}_{2}$, and $92.7 \% \mathrm{CO}_{2}$. The dissolved oxygen concentration $\left(\mathrm{dO}_{2}\right)$ was below $0.03 \%$ oxygen saturation.

To determine biomass dry weight concentration, triplicate $5 \mathrm{ml}$ samples from the culture suspension were filtered through preweighed $0.45 \mu \mathrm{m}$ filters and dried to constant weight in a vacuum oven at $70^{\circ} \mathrm{C}$. After steady state, both chemostats were sampled for mRNA isolation and Illumina sequencing.

\section{BATCH CULTIVATION}

Cells of SolV grown at maximal growth rate $\left(\mu_{\max }\right)$, without any nitrogen, $\mathrm{O}_{2}$, and $\mathrm{CH}_{4}$ limitation were obtained in 1 liter serum bottles, containing $50 \mathrm{ml}$ medium (with $4 \mathrm{mM}$ ammonium, $2 \%$ fangaia soil extract, and at pH 2, Khadem et al., 2010) and sealed with red butyl rubber stoppers. Incubations were performed in duplicate and contained in (v/v) $10 \% \mathrm{CH}_{4}, 5 \% \mathrm{CO}_{2}$, and $18 \% \mathrm{O}_{2}$ at $55^{\circ} \mathrm{C}$ with shaking at $180 \mathrm{rpm}$. Exponentially growing cells were collected for mRNA isolation and Illumina sequencing.

\section{GAS AND AMMONIUM ANALYSES}

Gas samples $(100 \mu \mathrm{l})$ were analyzed for methane $\left(\mathrm{CH}_{4}\right)$, carbon dioxide $\left(\mathrm{CO}_{2}\right)$, and oxygen $\left(\mathrm{O}_{2}\right)$ on an Agilent series 6890 gas chromatograph (GC) equipped with Porapak Q and Molecular Sieve columns and a thermal conductivity detector as described before (Ettwig et al., 2008).

Ammonium concentrations were measured using the orthophthaldialdehyde (OPA) method (Taylor et al., 1974).

\section{TRANSCRIPTOME ANALYSIS}

The draft genome sequence of strain SolV (Khadem et al., 2012) was used as the template for the transcriptome analysis. Cells were harvested by centrifugation and $3.1 \mathrm{mg}$ dry weight cells were used for isolation of mRNA, and subsequent synthesis of cDNA (328 ng) was done as described before (Ettwig et al., 2010). The cDNA was used for Illumina sequencing (RNA-Seq) as described before (Ettwig et al., 2010; Kartal et al., 2011). Expression analysis was performed with the RNA-Seq Analysis tool from the CLC Genomic Workbench software (version 4.0, CLC-Bio, Aarhus, Danmark) and values are expressed as RPKM (Reads Per Kilobase of exon model per Million mapped reads; Mortazavi et al., 2008).

\section{RESULTS AND DISCUSSION PHYSIOLOGY OF "CA. M. FUMARIOLICUM" SOLV GROWING WITH AND WITHOUT NITROGEN SOURCE AND UNDER OXYGEN LIMITATION}

Prior to the expression studies the physiological properties of strain solV were examined in batch and chemostat continuous culture. These studies showed that strain SolV in batch culture had a maximum growth rate of 0.07 and $0.04 \mathrm{~h}^{-1}$, with ammonium or nitrate as nitrogen source, respectively (Table 1 ). In the absence of ammonium and nitrate "Ca. M. fumariolicum" SolV cells were able to fix atmospheric $\mathrm{N}_{2}$ only at headspace oxygen concentration below 1\% (Khadem et al., 2010). The additional reduction steps of nitrate to ammonium could explain the observed increase in doubling time with nitrate compared to ammonium. The slower growth rate with $\mathrm{N}_{2}$ as nitrogen source was expected, since $\mathrm{N}_{2}$ fixation is an endergonic process, which needs about 16 mol ATP 
Table 1 | Description of batch and chemostat cultures of "Ca. Methylacidiphilum fumariolicum" SolV.

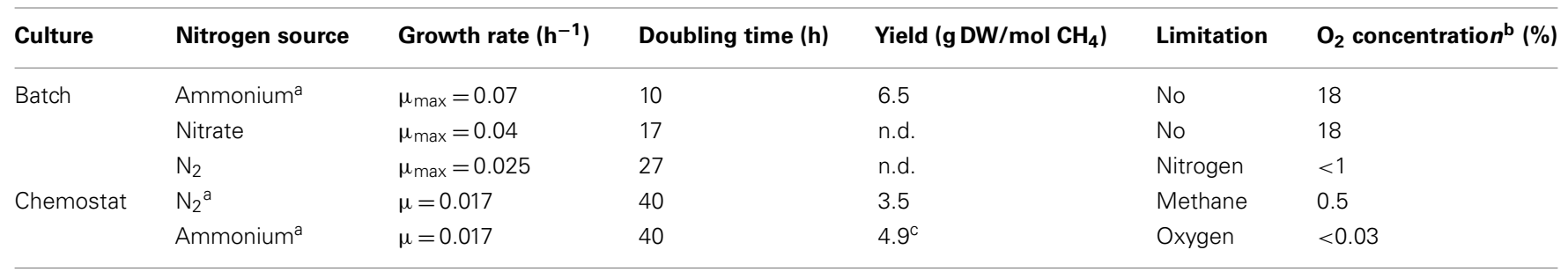



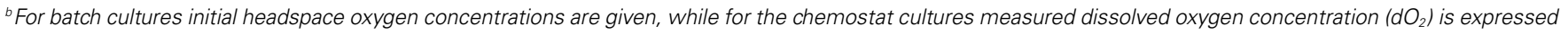
as \% oxygen saturation $\left(100 \%\right.$ equals $800 \mu \mathrm{mol} / \mathrm{l}$ at $\left.55^{\circ} \mathrm{C}\right)$.

${ }^{c}$ Calculated from $O D_{600}$ comparisons at steady state.

per mol $\mathrm{N}_{2}$ fixed (Dixon and Kahn, 2004). Based on the $\mu_{\max }$ data obtained, strain SolV seems to prefer ammonium, which is also the most likely nitrogen source in its natural environment.

Continuous cultivation of strain SolV cells in a chemostat at $\mathrm{pH} 2$ under nitrogen fixing conditions, was performed at dissolved oxygen concentrations $\left(\mathrm{dO}_{2}\right)$ equal to $0.5 \%$ oxygen saturation and without ammonium or nitrate (Table 1). Growth was limited by $\mathrm{CH}_{4}$ liquid-gas transfer in this chemostat culture (Khadem et al., 2010). The growth rate $\left(0.017 \mathrm{~h}^{-1}\right)$ is $68 \%$ of the $\mu_{\max }\left(0.025 \mathrm{~h}^{-1}\right)$ obtained in $\mathrm{N}_{2}$ fixing batch cultures.

For continuous cultivation of strain SolV under oxygen limitation and in the presence of excess methane and ammonium, the chemostat was supplied with medium at a dilution rate of $0.017 \mathrm{~h}^{-1}$ (Table 1). This resulted in a $\mathrm{dO}_{2}$ equal to $0.03 \%$ oxygen saturation $(<0.24 \mu \mathrm{mol} / \mathrm{l})$.

After a steady state was obtained in the chemostat, the stoichiometry of $\mathrm{CH}_{4}$ oxidation, and cell yield under $\mathrm{N}_{2}$ fixing and $\mathrm{O}_{2}$ limiting conditions were determined. Under $\mathrm{O}_{2}$ limitation the stoichiometry of $\mathrm{CH}_{4}$ oxidation was the same as reported, for excess ammonium and $\mathrm{O}_{2}$ (Pol et al., 2007). However, under $\mathrm{N}_{2}$ fixing conditions, a slightly higher consumption of $\mathrm{O}_{2}$ and production of $\mathrm{CO}_{2}$ was found (Khadem et al., 2010). This coincides with the lower cell yield of the nitrogen fixing chemostat culture of strain SolV (Table 1).

Three of the above described physiological conditions were selected for a genome wide transcriptome analysis (Table 1), e.g., exponentially growing cells (batch culture at $\mu_{\max }$ ) and cells from nitrogen or oxygen limited chemostat cultures.

\section{WHOLE GENOME TRANSCRIPTOME ANALYSIS OF “CA. $M$. FUMARIOLICUM" SOLV}

The SolV transcriptome was characterized using RNA-Seq. RNA was prepared from the three different cell cultures (see above), converted to cDNA and sequenced. The Illumina Genome Analyzer reads ( $75 \mathrm{bp}$ ) were first mapped to the ribosomal RNA operon and mapped reads were discarded. The unmapped reads $\left(3.5 \times 10^{6}, 3.2 \times 10^{6}\right.$, and $2.0 \times 10^{6}$ reads for $\mu_{\max }, \mathrm{N}_{2}$ fixing, and $\mathrm{O}_{2}$ limited cells, respectively) were mapped to the CDS, tRNA, and ncRNA sequences extracted from the genome sequence of strain SolV (Khadem et al., 2012). The total number of reads obtained and mapped for each sampled culture together with the calculated expression levels (RPKM) are provided File $\mathrm{S} 1$ in Supplementary Material (RNA-Seq_SolV.xls). We selected a set of 394 housekeeping genes (in total $443 \mathrm{kbp}$ ) involved in energy generation, in ribosome assembly, carbon fixation (CBB cycle), C1 metabolism (except for pmo), amino acid synthesis, cell wall synthesis, translation, transcription, DNA replication, and tRNA synthesis for the three conditions, to compare baseline expression levels (File S2 in Supplementary Material; Housekeeping genes.xls). For this gene set all ratios of expression between conditions were $>0.5$ and $<2$. The robustness of the transcriptome data were checked by the method of Chaudhuri et al. (2011) in which the expression levels $(\log 2(\mathrm{RPKM}+1))$ of the 394 gene set for the three conditions were plotted against each other. This resulted in correlation coefficients of $0.70,0.86$, and 0.86 (Figure A1 in Appendix), which are only slightly lower than those of technical replicates as reported by Chaudhuri et al. (2011).

In the following paragraphs, the differences in expression pattern under the various cultivation conditions with respect to energy, carbon, nitrogen, and hydrogen metabolism of strain SolV will be presented and discussed.

\section{ENERGY METABOLISM}

Genes involved in $\mathrm{CH}_{4}$ oxidation pathway (Hanson and Hanson, 1996; Chistoserdova et al., 2009) and their RPKM values are presented in (Table 2). In the genome data of the verrucomicrobial methanotrophs no genes encoding for the soluble cytoplasmic form of the methane monooxygenase (sMMO) were found (Hou et al., 2008; Khadem et al., 2012). However, three pmoCAB operons, encoding for the three subunits of particulate membraneassociated form (pMMO) were predicted. Transcriptome analysis of "Ca. M. fumariolicum" SolV showed differential expression of two of the three different operons. One of the pmoCAB operons ( $p m o C A B 2)$ was highly expressed (RPKM values $10.9 \times 10^{3}$ to $45 \times 10^{3}$, Figure 1$)$ in cells growing at $\mu_{\max }$ with excess ammonium and oxygen (initial headspace concentration of $18 \%$ ). The other two pmoCAB operons were hardly expressed under these culture conditions (RPKM 21-253). The cells from $\mathrm{CH}_{4}$ limited $\mathrm{N}_{2}$ fixing chemostat culture and the $\mathrm{O}_{2}$ limited chemostat culture with $\mathrm{dO}_{2}$ of 0.5 and $0.03 \%$ oxygen saturation, respectively, showed a remarkable different expression pattern of the pmoCAB operons. Under these conditions the pmoCAB1 operon was highly expressed (RPKM values $4.1 \times 10^{3}$ to $25 \times 10^{3}$ ) while expression of the pmoCAB2 operon was down regulated 40 times compared to the batch culture. The pmoCAB3 operon was hardly expressed in cells from the two chemostat cultures, expression values being 
Table 2 | Transcription of genes involved in oxidation of $\mathrm{CH}_{4}$ in "Ca. M. fumariolicum" strain SolV.

\begin{tabular}{|c|c|c|c|c|c|}
\hline Enzyme & Gene name & GenBank identifier & \multicolumn{3}{|c|}{ Expression level (RPKM) } \\
\hline & pmoA1 & Mfum_790002 & 37 & 4148 & 11804 \\
\hline & pmoB1 & Mfum_790001 & 181 & 16550 & 20004 \\
\hline \multirow[t]{2}{*}{ Methane monooxygenase_2 } & pmoc2 & Mfum_780001 & 45059 & 1405 & 1087 \\
\hline & pmoB2 & Mfum_770003 & 10930 & 467 & 712 \\
\hline \multirow[t]{3}{*}{ Methane monooxygenase_3 } & pmoc3 & Mfum_480006 & 253 & 148 & 101 \\
\hline & pmoA3 & Mfum_480005 & 45 & 44 & 24 \\
\hline & pmoB3 & Mfum_480007 & 21 & 17 & 15 \\
\hline Methanol dehydrogenase & $m x a F / x o x F$ & Mfum_190005 & 5945 & 2434 & 7554 \\
\hline Periplasmic binding protein & mxaJ & Mfum_190004 & 941 & 1548 & 629 \\
\hline & $p q q D$ & Mfum_710019 & 32 & 26 & 55 \\
\hline & $p q q D$ & Mfum_80009 & 108 & 118 & 195 \\
\hline & pqqE & Mfum_80008 & 525 & 1078 & 766 \\
\hline & $p q q F$ & Mfum_690050 & 527 & 339 & 737 \\
\hline \multirow[t]{3}{*}{$\mathrm{NADPH}$ :quinone reductase } & qor1 & Mfum_270035 & 330 & 236 & 1092 \\
\hline & qor2 & Mfum_300032 & 608 & 690 & 509 \\
\hline & qor3 & Mfum_820025 & 117 & 77 & 128 \\
\hline \multirow[t]{2}{*}{ Zn-dependent alcohol dehydrogenase } & $\operatorname{adhP1}$ & Mfum_310051 & 216 & 397 & 218 \\
\hline & adhP2 & Mfum_680019 & 165 & 96 & 196 \\
\hline \multirow[t]{2}{*}{ Aldehyde dehydrogenase } & dhaS1 & Mfum_940074 & 58 & 68 & 73 \\
\hline & dhaS2 & Mfum_840001 & 1345 & 1008 & 1337 \\
\hline & $f d s C$ & Mfumv1_80013 & 298 & 75 & 182 \\
\hline & $f d s D$ & Mfumv1_80016 & 313 & 260 & 62 \\
\hline Formate dehydrogenase & $f d h$ & Mfumv1_50001 & 233 & 186 & 257 \\
\hline \multirow[t]{2}{*}{ Methylamine dehydrogenase } & $\operatorname{mau} A$ & Mfumv1_700106 & 45 & 24 & 101 \\
\hline & mauB & Mfumv1_700109 & 220 & 199 & 168 \\
\hline
\end{tabular}

The mRNA expression is expressed as RPKM according to Mortazavi et al. (2008). Changes in expression in the chemostat cultures ( $\mathrm{N}_{2}$ fixing cells or $\mathrm{O}_{2}$ limited cells) compared to batch culture cells growing at $\mu_{\max }$ are indicated by shading: up regulation $>2$ times (dark gray), down regulation $<0.5$ (light gray).

identical to that of the cells at $\mu_{\max }$. Although other factors like growth rate, cell density, etc., could have an effect, the results point to a regulation of the $p m o C A B 1 / p m o C A B 2$ genes by the oxygen concentration. Since the $p m o C A B 3$ operon was not expressed under the conditions tested, other growth conditions have to be tested to elucidate the regulation and function of this pMMO. In a recent study, qPCR was used to investigate expression of the four pmoA genes of "Ca. M. kamchatkense" Kam1 (Erikstad et al., 2012). The pmoA2 gene was 35-fold stronger expressed than the other copies. Suboptimal temperature and $\mathrm{pH}$ conditions did not change this pattern. Other limitations were not tested. Grow on methanol resulted in a 10-fold decreased expression of pmoA2.

Also some proteobacterial methanotrophs are known to contain multiple copies of pmo operons (Semrau et al., 1995; Murrell et al., 2000). Within sequenced genomes of gammaproteobacterial methanotrophs two nearly sequence-identical copies of pmoCAB1 were found. It is thought that sequence-identical copies have arisen through gene duplications and insertion. Mutation studies in Methylococcus capsulatus Bath have demonstrated that both pMMO's were required for growth (Stolyar et al., 1999). More 




FIGURE 1 | Expression of the three pmoCAB operons, encoding the three subunits of the particulate methane monooxygenase (pMMO). Values from batch culture cells growing at $\mu_{\max }(\square), N_{2}$ fixing cells ( $\square$ ), and $\mathrm{O}_{2}$ limited cells $(\square)$ are expressed as RPKM (Mortazavi et al., 2008).

Expression of $m x a F$ ( $x O x F$ ) encoding methanol dehydrogenase is shown for comparison.

sequence-divergent copies ( $p m o \mathrm{CAB} 2$ ) were shown to be widely distributed in alphaproteobacterial methanotrophs (Yimga et al., 2003). Recently it was found that some genera of gammaproteobacterial methanotrophs also posses a sequence-divergent particulate methane monooxygenase, depicted pXMO (Tavormina et al., 2011). Unlike the CAB gene order of the pmo operon the pxm operon shows an ABC gene order. The presence of sequencedivergent copies suggests alternative physiological function under different environmental conditions. Methylocystis sp. strain SC2 was shown to possess two pMMO isozymes, encoded by pmoCAB1 and pmoCAB2 operons. The pmoCAB1 operon was expressed by strain SC2 at mixing ratios $>600 \mathrm{ppmv} \mathrm{CH}_{4}$, while growth and concomitant oxidation of methane at concentrations $<600$ 700 ppmv was due to the expression of pmoCAB2 (Baani and Liesack, 2008). In this case the methane concentration seems to control the up- and down regulation of the different pMMOs.

The second step in $\mathrm{CH}_{4}$ oxidation pathway is the conversion of methanol to formaldehyde by methanol dehydrogenase. Methanol dehydrogenase activity in strain SolV could be demonstrated but the gene cluster encoding this activity seems to be rather different compared to proteobacterial methanotrophs. The mxaFJGIRSACKLDEH cluster encoding the methanol dehydrogenase $(m x a F I)$, a cytochrome $(m x a G)$, a solute binding protein $(m \times a J)$, and accessory proteins (Chistoserdova et al., 2003; Ward et al., 2004; Chen et al., 2010) was absent in the verrucomicrobial methanotrophs (Hou et al., 2008; Khadem et al., 2012) and found to be replaced by a mxaFJG operon. In addition the gene cluster $p q q A B C D E F$ encoding proteins involved in biosynthesis of the methanol dehydrogenase cofactor pyrroloquinoline quinone was present. The expression of these genes did not vary much under the conditions tested (Table 2; Figure 1).

Formaldehyde, the product from the methanol dehydrogenase, is a key intermediate in methanotrophs. It may be oxidized for energy and detoxification, or fixed into cell carbon via the ribulose monophosphate pathway (RuMP) or serine cycle (see below, Hanson and Hanson, 1996; Chistoserdova et al., 2009). The canonical formaldehyde oxidation pathway requires folate as a cofactor for $\mathrm{C}_{1}$ transfer and formate dehydrogenase complexes (see below). The classical gene folA involved in the last step of folatebiosynthesis (encoding dihydrofolate reductase, FolA) is absent in "Ca. Methylacidiphilum" strains V4 and SolV. Hou et al. (2008) suggested that the role of this enzyme could be taken over by an alternative dihydropteroate synthase (FolP). The gene encoding for this enzyme was also present in strain SolV and was constitutively expressed at RPKM values of 133-236. The presence of the folD gene in the "Ca. Methylacidiphilum" strains (V4 and SolV) and expression data of this gene in strain SolV (Table 2), indeed suggest that conversion of formaldehyde is tetrahydrofolate-dependent. The "archaeal" tetrahydromethanopterin cofactor-based pathway for $\mathrm{C} 1$ transfer found in other methylotrophs is not present in the genomes of the "Ca. Methylacidiphilum" strains (Hou et al., 2008; Khadem et al., 2012).

Formaldehyde can also directly be oxidized by a formaldehyde dehydrogenase. The genome data of stain SolV reveal several candidates for formaldehyde oxidation: a NADPH:quinone reductase (or related $\mathrm{Zn}$-dependent oxidoreductases), $\mathrm{Zn}$-dependent alcohol dehydrogenases or the NAD-dependent aldehyde dehydrogenases. The genes encoding for these enzymes were expressed under all conditions tested (Table 2). A role for these enzymes should be further supported by enzyme purification and characterization studies. Genes encoding for soluble and membrane bound NAD-dependent formate dehydrogenases were also predicted from the draft genome of strain SolV and there expression levels were not significantly different the same under all experimental conditions (Table 2). This enzyme performs the last step of $\mathrm{CH}_{4}$ oxidation, converting formate into $\mathrm{CO}_{2}$.

\section{CARBON METABOLISM (CARBON FIXATION)}

The genome data of the verrucomicrobial methanotrophs (Hou et al., 2008; Khadem et al., 2012) showed differences in carbon assimilation compared to proteobacterial methanotrophs (Chistoserdova et al., 2009). Analyses of the draft genome of " $C a . M$. fumariolicum" strain SolV revealed that the key genes needed for an operational RuMP pathway, hexulose-6-P synthase and hexulose6-P isomerase were absent. In addition, the crucial genes encoding key enzymes of the serine pathway, malyl coenzyme A lyase, and glycerate kinase, were not found (Khadem et al., 2011). However, all genes required for an active $\mathrm{CBB}$ cycle could be identified in the SolV genome. These genes were highly expressed in both chemostat cultures (Table A1 in Appendix), to levels identical to those of cells in batch cultures growing at $\mu_{\max }$ (Khadem et al., 2011). The constitutive expression in all cell cultures was expected, assuming biomass carbon in strain SolV growing on methane can only be derived from fixation of $\mathrm{CO}_{2}$ via the $\mathrm{CBB}$ cycle (Khadem et al., 2011). Our transcriptome data of the chemostat cultures and batch cultures showed low expression of the $c b b R$ gene, encoding a possible RuBisCO operon transcriptional regulator. The $c b b R$ gene product is a LysR-type transcriptional regulator and the key activator protein of $c b b$ operons in facultative autotrophs (Bowien and Kusian, 2002). As an autotroph, strain SolV may not need much 
regulation of the CBB cycle genes. For strain V4 a coupling of this $c b b R$ gene to nitrate reduction and transport was suggested (Hou et al., 2008).

Although, the genes encoding for the ribulose-1,5-bisphosphate carboxylase/oxygenase (RuBisCO), the key enzyme of the $\mathrm{CBB}$ cycle was found in the genome of some proteobacterial methanotrophs like M. capsulatus Bath (Ward et al., 2004) and Methylocella silvestris BL2 (Chen et al., 2010) and the non-proteobacterial methanotroph "Candidatus Methylomirabilis oxyfera" (Ettwig et al., 2010), autotrophic growth in liquid cultures has not been reported for these methanotrophs yet.

\section{CARBOHYDRATE METABOLISM}

The presence and transcription of genes involved in the pentose phosphate pathway suggested the possibility of gluconeogenesis in strain SolV (Table A1 in Appendix). In M. capsulatus Bath, gluconeogenesis was suggested as follows: a putative phosphoketolase, condenses pyruvate, and glyceraldehyde3-phosphate into xylulose-5-phosphate, which in turn is fed into the ribulose-5-phosphate pool for formation of glucose-6phosphate through the pentose phosphate pathway (Ward et al., 2004). Since a putative phosphoketolase is also present and expressed in strain SolV, gluconeogenesis might take place in the same way. Another possibility for the production of glucose-6phosphate from glyceraldehyde-3-phosphate would be the consecutive action of triose-P-isomerase, fructose-1,6-bisphosphate aldolase, fructose-1,6-bisphosphate phosphatase, and glucose-6-P isomerase. All genes encoding these enzymes are expressed under the growth conditions tested (Table A1 in Appendix).

In many gammaproteobacterial methanotrophs, the tricarboxylic acid (TCA) cycle is believed to be incomplete, because they lack the $\alpha$-ketoglutarate dehydrogenase activity (Hanson and Hanson, 1996). However in the M. capsulatus genome homologs of this enzyme were indentified, suggesting that the TCA cycle might operate in this microorganism (Ward et al., 2004). Alphaproteobacterial methanotrophs are known to have a complete TCA cycle (Hanson and Hanson, 1996; Dedysh et al., 2002; Chen et al., 2010). The genes encoding for the TCA cycle enzymes were predicted from the genomes of strains V4 and SolV (Hou et al., 2008; Khadem et al., 2012). Our transcriptome analysis showed that these genes were expressed under the conditions applied, with slightly lower expression levels under $\mathrm{N}_{2}$ fixing conditions (Table A2 in Appendix). The presence of an operational TCA cycle in strain SolV suggests that growth on two carbon compounds like acetate should be possible. The presence and transcription of a gene encoding acetyl-coenzyme A synthetase (acs), allows acetate to be activated and fed into the TCA cycle (Table A2 in Appendix). Three alphaproteobacterial genera Methylocella, Methylocapsa, and Methylocystis, which were shown to be able to grow or survive on acetate, also posses a TCA cycle (Dedysh et al., 2005; Dunfield et al., 2010; Belova et al., 2011; Semrau et al., 2011).

\section{POTENTIAL CARBON AND ENERGY STORAGE}

Many bacteria start to accumulate reserve polymers when enough supply of suitable carbon is available, but nitrogen is limited (Wanner and Egli, 1990). This phenomenon is also known for methanotrophs (Pieja et al., 2011). Recently it was shown that type II methanotrophs contained the gene phaC, which encodes for the poly-3-hydroxybutyrate (PHB) synthase enable them to produce PHB (Pieja et al., 2011). At least three genes (phaC, phaA, phaB) were considered to be crucial for PHB synthesis. These genes are absent in type I methanotrophs and in the "Ca. Methylacidiphilum" strains (Hou et al., 2008; Khadem et al., 2012). However, genes encoding for glycogen synthesis, degradation, and transport (glycogen synthase, glycogen debranching enzyme, and ADP-glucose pyrophosphorylase) were predicted based on the draft genome of strain SolV. These genes were expressed under all conditions tested (Table A3 in Appendix). This supports the ability of carbon storage by strain SolV, but further physiological studies with cells growing under excess of carbon and nitrogen limitation are needed. Thus far literature on glycogen synthesis in methanotrophs is sparse, but several of the publicly available genomes of proteobacterial methanotrophs contain glycogen synthesis genes (M. capsulatus str. Bath; Methylomonas methanica MC09; Methylomicrobium alcaliphilum; Methylocystis sp. ATCC 49242; http://www.ncbi.nlm.nih.gov/genomes).

The presence and constitutive expression of genes involved in phosphate transport, polyphosphate synthesis, and utilization (ABC-type phosphate transport system, polyphosphate kinase, adenylate kinase, and exopolyphosphatase; Table A3 in Appendix) suggest that strain SolV is able to store polyphosphate as energy and phosphorus reserve.

\section{NITROGEN METABOLISM: AMMONIUM, NITRATE, AND AMINO ACID METABOLISM}

Based on the genome and supported by the transcriptome data the main route for ammonium assimilation in " $\mathrm{Ca}$. M. fumariolicum" occurs via glutamine synthase $(g \ln A)$ /glutamate synthase $(g l t B)$ and/or the alanine and glutamate dehydrogenases (ald, $g d h)$. Expression values of ald and $g d h$ were about three- to fivefold lower compared to $g \ln \mathrm{A}$ and $g l t \mathrm{~B}$ under the conditions tested (Table 3). Also the genes encoding the glutamine-hydrolyzing carbamoyl-phosphate synthase (carA and $\operatorname{car} B$ ) were constitutively expressed. This enzyme coverts glutamine and carbon dioxide into glutamate and carbamoyl-phosphate. The latter substrate can be fed into the urea cycle. Except for the gene encoding arginase all other genes $(\operatorname{argDHFG})$ encoding enzymes of the urea cycle were present and constitutively expressed. The most likely function of this partial cycle will be arginine synthesis. For strain V4 it was suggested that the ornithine needed can be supplied by 4 aminobutyrate aminotransferase through a part of the TCA cycle and glutamate synthesis (Hou et al., 2008). In strain SolV, the gene encoding 4-aminobutyrate aminotransferase is also present and expressed. Other methylotrophs possess neither arginase nor ArgD (Hou et al., 2008).

The genes encoding nitrate/nitrite transporters and the assimilatory nitrite and nitrate reductases showed very low expression levels (8-117), probably due to the absence of nitrate in the growth media used. The ammonium transporter gene $(a m t B$ type) is three- to fourfold upregulated in $\mathrm{N}_{2}$ fixing cells, which reflects increased ammonium scavenging under nitrogen limited conditions. 
Table 3 | Transcription of genes involved in nitrogen metabolism in "Ca. M. fumariolicum" strain SolV.

\begin{tabular}{|c|c|c|c|c|c|}
\hline \multirow[t]{2}{*}{ Enzyme } & \multirow[t]{2}{*}{ Gene name } & \multirow[t]{2}{*}{ GenBank identifier } & \multicolumn{3}{|c|}{ Expression level (RPKM) } \\
\hline & & & Cells at $\mu_{\max }$ & $\mathrm{N}_{2}$ fixing cells & $\mathrm{O}_{2}$ limited cells \\
\hline Glutamine synthetase & $g \ln A$ & Mfum_90015 & 1542 & 1052 & 725 \\
\hline Glutamine synthetase regulatory protein PII & $g \ln B$ & Mfum_90016 & 1039 & 1701 & 914 \\
\hline UTP:GInB (Protein PII) uridylyltransferase & $g \ln D$ & Mfum_230007 & 169 & 111 & 145 \\
\hline Nitrogen regulatory protein PII & $g \ln K$ & Mfum_140026 & 166 & 60 & 203 \\
\hline Alanine dehydrogenase & ald & Mfum_290047 & 248 & 279 & 256 \\
\hline Glutamate dehydrogenase & $g d h A$ & Mfum_810044 & 436 & 182 & 500 \\
\hline Glutamate synthase alpha chain & $g / t B$ & Mfum_940063 & 1343 & 1360 & 1355 \\
\hline Glutamate synthase beta chain & $g l t D$ & Mfum_270076 & 133 & 114 & 125 \\
\hline \multirow[t]{2}{*}{ Ornithine/acetylornithine aminotransferase } & $\operatorname{argD1}$ & Mfum_190040 & 736 & 736 & 410 \\
\hline & $\arg D 2$ & Mfum_1010035 & 383 & 421 & 410 \\
\hline Argininosuccinate lyase & $\operatorname{argH}$ & Mfum_970020 & 226 & 186 & 107 \\
\hline Ornithine carbamoyltransferase & $\arg F$ & Mfum_1010036 & 286 & 267 & 375 \\
\hline Argininosuccinate synthase & $\arg G$ & Mfum_270005 & 725 & 527 & 678 \\
\hline Carbamoyl-phosphate synthase small chain & $\operatorname{car} A$ & Mfum_270024 & 450 & 340 & 479 \\
\hline Carbamoyl-phosphate synthase large chain & $\operatorname{car} B$ & Mfum_700048 & 395 & 267 & 504 \\
\hline Ammonium transporter & $a m t B$ & Mfum_430001_160001a & 343 & 1143 & 420 \\
\hline Nitrate $A B C$ transporter, nitrate-binding protein & $\operatorname{tau} A$ & Mfum_140012 & 28 & 117 & 33 \\
\hline Nitrate transporter & nasA & Mfum_140017 & 22 & 26 & 16 \\
\hline Assimilatory nitrate reductase large subunit & bisC & Mfum_140014 & 13 & 14 & 8 \\
\hline Assimilatory nitrite reductase & $\operatorname{nir} B$ & Mfum_140015 & 14 & 40 & 13 \\
\hline Ferredoxin subunit of nitrite reductase & $\operatorname{nirD}$ & Mfum_140016 & 32 & 18 & 16 \\
\hline Signal transduction histidine kinase with PAS domain & $n \operatorname{tr} B$ & Mfum_920004 & 283 & 294 & 250 \\
\hline \multirow[t]{4}{*}{ Signal transduction response regulator, NtrC family } & $n \operatorname{trC1}$ & Mfum_110018 & 90 & 76 & 67 \\
\hline & ntrC2 & Mfum_170043 & 116 & 110 & 111 \\
\hline & $n \operatorname{trC3}$ & Mfum_260013 & 623 & 361 & 525 \\
\hline & $n t r C 4$ & Mfum_920003 & 225 & 154 & 216 \\
\hline Hydroxylamine oxidoreductase & haoA & Mfum_970027 & 357 & 124 & 568 \\
\hline Nitric oxide reductase B subunit & norB & Mfum_970100 & 261 & 120 & 342 \\
\hline Nitric oxide reductase subunit $\mathrm{C}$ & norC & Mfum_970099 & 192 & 93 & 139 \\
\hline Nitrite reductase (NO-forming) & nirk & Mfum_270071 & 72 & 63 & 200 \\
\hline DNA-binding response regulator, NarL family & $m \times a B$ & Mfum_1030004 & 232 & 74 & 142 \\
\hline DNA-binding response regulator, LuxR family & citB1 & Mfum_790006 & 1760 & 5611 & 4679 \\
\hline DNA-binding response regulator, LuxR family & citB2 & Mfum_580001 & 394 & 200 & 239 \\
\hline
\end{tabular}

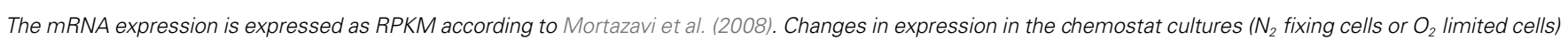

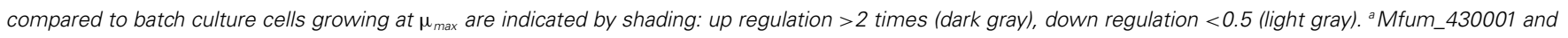
Mfum_160001 encode the $\mathrm{N}$ - and C-terminal part, respectively.

\section{NITROGEN FIXATION}

The genomes of strain SolV and strain V4 show a complete set of genes necessary for $\mathrm{N}_{2}$ fixation (Hou et al., 2008; Khadem et al., 2012). Most of these genes and their organization in putative operons resemble those of M. capsulatus Bath (Ward et al., 2004), a gammaproteobacterial methanotroph that has been shown to fix atmospheric $\mathrm{N}_{2}$ (Oakley and Murrell, 1991). $\mathrm{N}_{2}$ fixation is widely distributed among methanotrophs as shown by the presence of both nifH gene fragments and acetylene reduction activity in a variety of alpha- and gammaproteobacterial methanotroph strains (Auman et al., 2001). Also the deep-sea anaerobic methane-oxidizing Archaea were shown to fix $\mathrm{N}_{2}$ and share the products with their sulfate-reducing bacterial symbionts (Dekas et al., 2009).
Gene expression data of strain SolV showed that all the genes involved in nitrogen fixation were upregulated only in absence of ammonium and nitrate indicating the effect of nitrogen availability on the expression of these genes (Table 4). The genes encoding for the nitrogenase (nifH, nifD, nifK) were 100- to 325-fold upregulated, while the gene involved in regulation (nif $A$ ) and the $\mathrm{Fe} / \mathrm{Mo}$ cofactor biosynthesis genes showed 30- to 235-fold increased expression levels. Our previous physiological studies already confirmed that nitrogenase was active in $\mathrm{N}_{2}$ fixing chemostat cultures (Khadem et al., 2010).

Growth on atmospheric nitrogen in the chemostat was only observed when the $\mathrm{dO}_{2}$ was below $0.5 \%$ oxygen saturation. Our previous batch incubations in the presence of ammonium and $0.5 \% \mathrm{O}_{2}$ saturation resulted in doubling time of $10 \mathrm{~h}$ 
Table 4 | Transcription of genes involved in nitrogen fixation in "Ca. M. fumariolicum" strain SolV.

Enzyme
Gene name GenBank identifier
Expression level (RPKM)

Cells at $\mu_{\max } \quad \mathrm{N}_{2}$ fixing cells $\mathrm{O}_{2}$ limited cells

Nitrogenase iron protein

Nitrogenase molybdenum-iron protein alpha chain

Nitrogenase molybdenum-iron protein beta chain

Nitrogenase Mo/Fe cofactor biosynthesis protein NifE

Nitrogenase Mo/Fe cofactor biosynthesis protein NifN

Protein NifX

Nif-specific regulatory protein

Nitrogenase Mo/Fe cofactor biosynthesis protein NifB

Pyruvate-flavodoxin oxidoreductase

NifQ family protein

Cysteine desulfurase

NifU-like protein involved in FeS cluster formation

Nitrogenase-stabilizing/protective protein NifW

NifZ domain protein

Electron transfer flavoprotein beta chain

Electron transfer flavoprotein alpha chain

Flavoprotein-ubiquinone oxidoreductase

Ferredoxin-like protein

Nitrogen fixation protein FixU

FeS cluster assembly scaffold protein, HesB/SufA family

FeS cluster assembly protein SufB

FeS cluster assembly protein SufD

FeS cluster assembly protein SufE family

FeS4 cluster protein with leucine rich repeats

Ferredoxin-like protein in nif region

Uptake hydrogenase large subunit

Uptake hydrogenase small subunit

Nickel/iron-hydrogenase I, small subunit

Nickel/iron-hydrogenase I, large subunit

$\mathrm{Ni}$,Fe-hydrogenase I cytochrome $b$ subunit

[NiFe] hydrogenase $\mathrm{Ni}$ incorporation protein HypA

[NiFe] hydrogenase Ni incorporation-associated protein HypB

[NiFe] hydrogenase metallocenter assembly protein HypC

[NiFe] hydrogenase expression/formation protein HypD

[NiFe] hydrogenase metallocenter assembly protein HypE

[NiFe] hydrogenase metallocenter assembly protein HypF

Hydrogenase expression protein $\mathrm{HupH}$

Hydrogenase expression/formation protein $\mathrm{HoxO}$

Hydrogenase maturation protease
nifH

nifD

nifK

nifE

nifN

nifX

nifA

nifB

nifJ

nifQ

nifS1

nifS2

nifS3

nifS4

nifS5

nifU

nifW

nifZ

fixA

fix $B$

fix $C$

fix $X$

fixU

SUfA 1

SUfA2

sufA3

sufB

sufD

sufE

frxA

hupB

hupS

hyaA

hya $B$

hyaC

hypA

hypB

hypC

hypD

hypE

hypF

hupH

hoxQ

hycl

\section{Mfum_690040}

Mfum_690039

Mfum_690038

Mfum_690037

Mfum_690036

Mfum_690035

Mfum_690018

Mfum_690029

Mfum_940083

Mfum_690020

Mfum_690022

Mfum_90010

Mfum_190023

Mfum_970062

Mfum_310028

Mfum_310029

Mfum_690011

Mfum_690023

Mfum_690010

Mfum_690009

Mfum_690008

Mfum_690007

Mfum_690015

Mfum_690026

Mfum_810040

Mfum_1020116

Mfum_970056

Mfum_970057

Mfum_110022

Mfum_690024

Mfum_690027

Mfum_50004

Mfum_50003

Mfum_870019

Mfum_870018

Mfum_50005

Mfum_730023

Mfum_870009

Mfum_870006

Mfum_870005

Mfum_870004

Mfum_870007

Mfum_50006

Mfum_730017

Mfum_730022

69

69

87

35

77

64

100

123

19

149

65

93

159

681

162

226

54

62

158

60

81

101

126

164

40

149

214

1099

663

375

88

112

92

186

2380

2566

122

119

421

830

1159

424

92

160

177

69

\section{2 fixing cells}

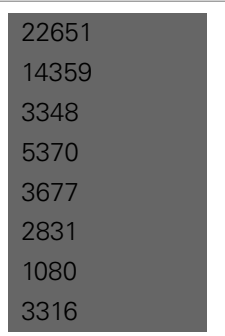

133

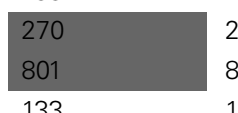

$133 \quad 116$

$491 \quad 486$

$275 \quad 145$

$151 \quad 264$

$16 \quad 79$

2260

$1373 \quad 50$

$3311 \quad 73$

$3043 \quad 69$

$3632 \quad 100$

$2917 \quad 135$

$2265 \quad 91$

$2301 \quad 22$

$43 \quad 71$

$143 \quad 183$

\begin{tabular}{l|l}
2409 & 622 \\
2169 & 279
\end{tabular}

$209 \quad 219$

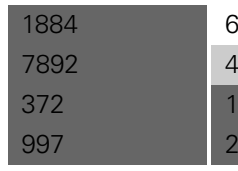

4157

1879

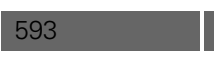

$110 \quad 95$

335692

$600 \quad 321$

$893 \quad 1246$

$476 \quad 759$

$81 \quad 167$

$44 \quad 89$

\begin{tabular}{l|l}
631 & 879 \\
169 & 136
\end{tabular}

The mRNA expression is expressed as RPKM according to Mortazavi et al. (2008). Changes in expression in the chemostat cultures ( $\mathrm{N}_{2}$ fixing cells or $\mathrm{O}_{2}$ limited cells) compared to batch culture cells growing at $\mu_{\max }$ are indicated by shading: up regulation $>2$ times (dark gray), down regulation $<0.5$ (light gray).

(Khadem et al., 2010). This indicates that in $\mathrm{N}_{2}$ fixing chemostat cultures, this low oxygen was not growth limiting. Maintaining a low oxygen concentration in both batch and chemostat is required for an active nitrogenase, since this enzyme is irreversibly damaged by $\mathrm{O}_{2}$ (Robson and Postgate, 1980). Low oxygen requirement for $\mathrm{N}_{2}$ fixation was also demonstrated for other proteobacterial 
methanotrophs (Murrell and Dalton, 1983; Takeda, 1988; Dedysh et al., 2004). The effect of high oxygen concentration on the expression of genes encoding $\mathrm{N}_{2}$ fixing enzymes, in absence of ammonium/nitrate still needs to be addressed in strain SolV.

Methanotrophic hydrogenases are considered to have a role in $\mathrm{N}_{2}$ fixation or $\mathrm{CH}_{4}$ oxidation. The role of hydrogenase as a source of reducing power for $\mathrm{CH}_{4}$ oxidation was demonstrated in M. capsulatus Bath (Hanczar et al., 2002). Hydrogen uptake and evolution activities during $\mathrm{N}_{2}$ fixation were reported for Methylosinus trichosporium (De Bont and Mulder, 1976) and Methylocystis T-1 (Takeda, 1988), respectively. However, knock out studies of $\Delta$ hupSL encoding for the large and small subunit of the $\mathrm{Ni} / \mathrm{Fe}-$ dependent hydrogenase in M. capsulatus Bath, did not show differences in viability under nitrogen fixing and non-nitrogen fixing condition in comparison to the wild strain (Csaki et al., 2001). Based on these results, the authors suggested that the hydrogenase is probably regulated by oxygen availability rather than by the hydrogen generated by the nitrogenase enzyme complex. Our expression data also show an increased expression under both nitrogen fixing and oxygen limited conditions (Table 4). Since under oxygen limitation the nitrogen fixing genes were not expressed, while the hydrogenase encoding genes were expressed to even higher levels, oxygen seems to be the regulatory factor for the latter set of genes.

The PII signal transduction proteins (encoded by $g \ln B$ and $g \ln K)$ are used to transduce the nitrogen status of the cell to the NtrB-NtrC two-component regulatory system and the $\sigma^{54}$ dependent $a m t B$ promoters to tune nif gene transcription (for a detailed overview see Dixon and Kahn, 2004). The $g \ln B$ gene of strain SolV was highly expressed under all conditions and slightly upregulated (1.5-fold) under $\mathrm{N}_{2}$ fixing conditions. Expression of $g \ln K$ was overall about fivefold lower and threefold downregulated under nitrogen fixing conditions. In addition genes encoding for uridylyltransferase $(g \ln D), \mathrm{NtrB}$, and $\mathrm{NtrC}$ showed expression levels under three conditions tested which did not significantly differ (Table 3). This suggests that in strain SolV the PII proteins are involved in sensing and regulating the status of fixed nitrogen in the cell. Transcription of the nif genes is regulated by nifA and nifL genes (Dixon and Kahn, 2004). The expression of nifA is regulated by oxygen and/or fixed nitrogen and nifL gene is involved in oxygen sensing. We could not identify a nifL gene in the genome of strain SolV (Khadem et al., 2012). However, nifA is present and was 30 -fold upregulated under $\mathrm{N}_{2}$ fixing conditions.

Nitrogenase is believed to be sensitive for reactive oxygen species (ROS), and during nitrogen fixation the level of ROS is reduced by up regulation of ROS-detoxifying genes. In Gluconacetobacter diazotrophicus upregulation of these genes was observed during nitrogen fixation (Alquéres et al., 2010). Although, in the genome of strain SolV two sodA genes encoding for superoxide dismutases can be identified, they both are highly expressed under all conditions tested (RPKM values: Mfum_810007, $797 \pm 163$; Mfum_980001, 961 \pm 669 ), but expression seems to be 1.5- to 3 -fold lower under $\mathrm{N}_{2}$ fixing and $\mathrm{O}_{2}$ limited conditions.

\section{NITROSATIVE STRESS}

The pMMO enzyme involved in the first step of $\mathrm{CH}_{4}$ oxidation in methanotrophs, also oxidizes ammonium which results in the formation of the intermediate hydroxylamine $\left(\mathrm{NH}_{2} \mathrm{OH}\right.$; Hanson and Hanson, 1996; Nyerges and Stein, 2009 and reference therein; Stein and Klotz, 2011). Ammonia-oxidizers can relay electrons from hydroxylamine oxidation to the quinone pool to drive energy production and cellular growth (Klotz and Stein, 2008), but methanotrophs lack this relay and can not produce energy from this oxidation. Since hydroxylamine is a highly toxic intermediate, methanotrophs rely on mechanisms to quickly remove it. In their natural habitat the "Ca. M. fumariolicum" cells are confronted with varying nitrogen levels $(1-28 \mathrm{mM}$, Khadem et al., 2010) which means that the cells have to balance assimilation and tolerance to reactive-N. Detoxification can be achieved by conversion of hydroxylamine back to ammonium or to nitrite through the use of a hydroxylamine reductase enzyme (HAO). The nitrite in turn can be converted to $\mathrm{N}_{2} \mathrm{O}$ via $\mathrm{NO}$ by putative denitrifying enzymes (nitrite reductase and NO-reductase, Campbell et al., 2011). Genes involved in these conversions may include hao, $c y t L, c y t S$, nirBD, nirS or nirK, and norCB. The genes hao, nor $C B$ were shown to be present in the genomes of the verrucomicrobial methanotrophs (Hou et al., 2008; Khadem et al., 2012), while a nirK homolog was only found in strain SolV. The gene inventory in methanotrophic bacteria for handling hydroxylamine or other toxic nitrosating intermediates and for those encoding putative denitrifying enzymes is diverse and unpredictable by phylotype or taxon (Stein and Klotz, 2011).

In our study we found that although expressed under all conditions tested, expression of hao and norBC were 1.5- to 4.5-fold lower under nitrogen fixing conditions (Table 3), which makes sense in view of the expected lower ammonium levels in the cells. However, for nirK expression was low $(\mathrm{RPKM}=63-72)$ except for the cells grown under oxygen limitation $(\mathrm{RPKM}=200)$.

\section{CONCLUSION}

In this study we analyzed the genome wide changes in expression during three different growth conditions which helped very much to understand the physiology of "Ca. M. fumariolicum" strain SolV. The analysis indicated that the two of the three pmoCAB operons are probably regulated by oxygen, although the effect of other factors like growth rate, cell density can not be excluded. Further, the hydrogen produced during $\mathrm{N}_{2}$ fixation can be recycled, and that nitrosative stress is counter acted. the results point to a regulation of the pmoCAB1/pmoCAB2 genes by the oxygen concentration.

The obtained information will be a guide to design future physiological and biochemical studies.

\section{ACKNOWLEDGMENTS}

This work was supported by Mosaic grant 62000583 from the Dutch Organization for Scientific Research-NWO. Mike S. M. Jetten is supported by ERC grant number 232937.

\section{SUPPLEMENTARY MATERIAL}

The Supplementary Material for this article can be found online at http://www.frontiersin.org/Evolutionary_and_Genomic_ Microbiology/10.3389/fmicb.2012.00266/abstract

File S1 | RNA-Seq analysis of "Ca. Methylacidiphilum fumariolicum" SolV grown under different conditions.

File S2 | Housekeeping genes to test robustness of transcriptome data. 


\section{REFERENCES}

Alquéres, S. M. C., Oliveira, J. H. M., Nogueira, E. M., Guedes, H. V., Oliveira, P. L., Camara, F., Baldani, J. I., and Martins, O. B. (2010). Antioxidant pathways are up-regulated during biological nitrogen fixation to prevent ROS-induced nitrogenase inhibition in Gluconacetobacter diazotrophicus. Arch. Microbiol. 192, 835-841.

Auman, A. J., Speake, C. C., and Lidstrom, M. E. (2001). nifH sequences and nitrogen fixation in type I and type II methanotrophs. Appl. Environ. Microbiol. 67, 4009-4016.

Baani, M., and Liesack, W. (2008). Two isozymes of particulate methane monooxygenase with different methane oxidation kinetics are found in Methylocystis sp. strain SCZ. Proc. Natl. Acad. Sci. U.S.A. 105, 10203-10208.

Belova, S. E., Baani, M., Suzina, N. E., Bodelier, P. L. E., Liesack, W., and Dedysh, S. N. (2011). Acetate utilization as a survival strategy of peatinhabiting Methylocystis spp. Environ. Microbiol. Rep. 3, 36-46.

Boetius, A., Ravenschlag, K., Schubert, C. J., Rickert, D., Widdel, F., Gieseke, A., Amann, R., Jorgensen, B. B., Witte, U., and Pfannkuche, O. (2000). A marine microbial consortium apparently mediating anaerobic oxidation of methane. Nature 407, 623-626.

Bowien, B., and Kusian, B. (2002). Genetics and control of CO2 assimilation in the chemoautotroph Ralstonia eutropha. Arch. Microbiol. 178, 85-93.

Campbell, M. A., Nyerges, G., Kozlowski, J. A., Poret-Peterson, A. T., Stein, L. Y., and Klotz, M. G. (2011). Model of the molecular basis for hydroxylamine oxidation and nitrous oxide production in methanotrophic bacteria. FEMS Microbiol. Lett. 322, 82-89.

Chaudhuri, R. R., Yu, L., Kanji, A., Perkins, T. T., Gardner, P. P., Choudhary, J., Maskell, D. J., and Grant, A. J. (2011). Quantitative RNAseq analysis of the Campylobacter jejuni transcriptome. Microbiology 157, 2922-2932.

Chen, Y., Crombie, A., Rahman, M. T., Dedysh, S. N., Liesack, W., Stott, M. B., Alam, M., Theisen, A. R., Murrell, J. C., and Dunfield, P. F. (2010). Complete genome sequence of the aerobic facultative methanotroph Methylocella silvestris BL2. J. Bacteriol. 192, 3840-3841.

Chistoserdova, L., Chen, S. W., Lapidus, A., and Lidstrom, M. E. (2003). Methylotrophy in Methylobacterium extorquens AM1 from a genomic point of view. J. Bacteriol. 185, 2980-2987.

Chistoserdova, L., Kalyuzhnaya, M. G. and Lidstrom, M. E. (2009). The expanding world of methylotrophic metabolism. Annu. Rev. Microbiol. 63, 477-499.

Conrad, R. (2009). The global methane cycle: recent advances in understanding the microbial processes involved. Environ. Microbiol. Rep. 1, 285-292.

Croucher, N. J., and Thomson, N. R. (2010). Studying bacterial transcriptomes using RNA-seq. Curr. Opin. Microbiol. 13, 619-624.

Csaki, R., Hanczar, T., Bodrossy, L., Murrell, J. C., and Kovacs, K. L. (2001). Molecular characterization of structural genes coding for a membrane bound hydrogenase in Methylococcus capsulatus (Bath). FEMS Microbiol. Lett. 205, 203-207.

De Bont, J. A. M., and Mulder, E. G. (1976). Invalidity of acetylene reduction assay in alkane utilizing, nitrogen-fixing bacteria. Appl. Environ. Microbiol. 31, 640-647.

Dedysh, S. N., Khmelenina, V. N., Suzina, N. E., Trotsenko, Y. A., Semrau, J. D., Liesack, W., and Tiedje, J. M. (2002). Methylocapsa acidiphila gen. nov., sp nov., a novel methaneoxidizing and dinitrogen-fixing acidophilic bacterium from Sphagnum bog. Int. J. Syst. Evol. Microbiol. 52, 251-261.

Dedysh, S. N., Knief, C., and Dunfield, P. F. (2005). Methylocella species are facultatively methanotrophic. $J$. Bacteriol. 187, 4665-4670.

Dedysh, S. N., Ricke, P., and Liesack, W. (2004). NifH and NifD phylogenies: an evolutionary basis for understanding nitrogen fixation capabilities of methanotrophic bacteria. Microbiology 150, 1301-1313.

Dekas, A. E., Poretsky, R. S., and Orphan, V. J. (2009). Deep-sea archaea fix and share nitrogen in methaneconsuming microbial consortia. Science 326, 422-426.

Dixon, R., and Kahn, D. (2004). Genetic regulation of biological nitrogen fixation. Nat. Rev. Microbiol. 2, 621-631.

Dunfield, P. F., Belova, S. E., Vorob’Ev, A. V., Cornish, S. L., and Dedysh, S. N. (2010). Methylocapsa aurea sp. nov., a facultative methanotroph possessing a particulate methane monooxygenase, and emended description of the genus Methylocapsa. Int. J. Syst. Evol. Microbiol. 60, 2659-2664.

Dunfield, P. F., Yuryev, A., Senin, P., Smirnova, A. V., Stott, M. B., Hou, S. B., Ly, B., Saw, J. H., Zhou, Z. M.,
Ren, Y., Wang, J. M., Mountain, B. W., Crowe, M. A., Weatherby, T. M., Bodelier, P. L. E., Liesack, W., Feng, L., Wang, L., and Alam, M. (2007). Methane oxidation by an extremely acidophilic bacterium of the phylum Verrucomicrobia. Nature 450, 879-883.

Erikstad, H. A., Jensen, S., Keen, T. J., and Birkeland, N. K. (2012). Differential expression of particulate methane monooxygenase genes in the verrucomicrobial methanotroph "Methylacidiphilum kamchatkense" Kam1. Extremophiles 16, 405-409.

Ettwig, K. F., Butler, M. K., Le Paslier, D., Pelletier, E., Mangenot, S., Kuypers, M. M. M., Schreiber, F., Dutilh, B. E., Zedelius, J., de Beer, D., Gloerich, J., Wessels, H. J. C. T., van Alen, T., Luesken, F., Wu, M. L., van de Pas-Schoonen, K. T., Op den Camp, H. J. M., Janssen-Megens, E. M., Francoijs, K. J., Stunnenberg, H., Weissenbach, J., Jetten, M. S. M., and Strous, M. (2010). Nitritedriven anaerobic methane oxidation by oxygenic bacteria. Nature 464, 543-550.

Ettwig, K. F., Shima, S., van de PasSchoonen, K. T., Kahnt, J., Medema, M. H., Op den Camp, H. J. M., Jetten, M. S. M., and Strous, M. (2008). Denitrifying bacteria anaerobically oxidize methane in the absence of Archaea. Environ. Microbiol. 10, 3164-3173.

Hanczar, T., Csaki, R., Bodrossy, L., Murrell, J. C., and Kovacs, K. L. (2002). Detection and localization of two hydrogenases in Methylococcus capsulatus (Bath) and their potential role in methane metabolism. Arch. Microbiol. 177, 167-172.

Hanson, R. S., and Hanson, T. E. (1996). Methanotrophic bacteria. Microbiol. Rev. 60, 439-471.

Hou, S. B., Makarova, K. S., Saw, J. H. W., Senin, P., Ly, B. V., Zhou, Z. M., Ren, Y., Wang, J. M., Galperin, M. Y., Omelchenko, M. V., Wolf, Y. I., Yutin, N., Koonin, E. V., Stott, M. B., Mountain, B. W., Crowe, M. A., Smirnova, A. V., Dunfield, P. F., Feng, L., Wang, L., and Alam, M. (2008). Complete genome sequence of the extremely acidophilic methanotroph isolate V4, Methylacidiphilum infernorum, a representative of the bacterial phylum Verrucomicrobia. Biol. Direct 3, $1-25$.

Islam, T., Jensen, S., Reigstad, L. J., Larsen, O., and Birkeland, N. K. (2008). Methane oxidation at $55^{\circ} \mathrm{C}$ and $\mathrm{pH} 2$ by a thermoacidophilic bacterium belonging to the Verrucomicrobia phylum. Proc. Natl. Acad. Sci. U.S.A. 105, 300-304.
Kartal, B., Maalcke, W. J., de Almeida, N. M., Cirpus, I., Gloerich, J., Geerts, W., Op den Camp, H. J. M., Harhangi, H. R., Janssen-Megens, E. M., Francoijs, K. J., Stunnenberg, H. G., Keltjens, J. T., Jetten, M. S. M., and Strous, M. (2011). Molecular mechanism of anaerobic ammonium oxidation. Nature 479, 127-130.

Khadem, A. F., Pol, A., Jetten, M. S. M., and Op den Camp, H. J. M. (2010). Nitrogen fixation by the verrucomicrobial methanotroph 'Methylacidiphilum fumariolicum' SolV. Microbiology 156, 1052-1059.

Khadem, A. F., Pol, A., Wieczorek, A., Mohammadi, S. S., Francoijs, K. J., Stunnenberg, H. G., Jetten, M. S. M., and Op den Camp, H. J. M. (2011). Autotrophic methanotrophy in Verrucomicrobia: Methylacidiphilum fumariolicum SolV uses the Calvin-Benson-Bassham cycle for carbon dioxide fixation. J. Bacteriol. 193, 4438-4446.

Khadem, A. F., Wieczorek, A. S., Pol, A., Vuilleumier, S., Harhangi, H. R., Dunfield, P. F., Kalyuzhnaya, M. G., Murrell, J. C., Francoijs, K-J., Stunnenberg, H. G., Stein, L. Y., DiSpirito, A. A., Semrau, J. D., Lajus, A., Médigue, C., Klotz, M. G., Jetten, M. S. M., and Op den Camp, H. J. M. (2012). Draft genome sequence of the volcano-inhabiting thermoacidophilic methanotroph Methylacidiphilum fumariolicum strain SolV. J. Bacteriol. 194, 3729-3730.

Klotz, M. G., and Stein, L. Y. (2008). Nitrifier genomics and evolution of the nitrogen cycle. FEMS Microbiol. Lett. 278, 146-456.

Malone, J. H., and Oliver, B. (2011). Microarrays, deep sequencing and the true measure of the transcriptome. BMC Biol. 9, 34. doi:10.1186/1741-7007-9-34

Mortazavi, A., Williams, B. A., McCue, K., Schaeffer, L., and Wold, B. (2008). Mapping and quantifying mammalian transcriptomes by RNA-Seq. Nat. Methods 5, 621-628.

Murrell, J. C., and Dalton, H. (1983). Nitrogen fixation in obligate methanotrophs. J. Gen. Microbiol. 129, 3481-3486.

Murrell, J. C., Gilbert, B., and McDonald, I. R. (2000). Molecular biology and regulation of methane monooxygenase. Arch. Microbiol. $173,325-332$.

Nyerges, G., and Stein, L. Y. (2009) Ammonia cometabolism and product inhibition vary considerably among species of methanotrophic 
bacteria. FEMS Microbiol. Lett. 297, Semrau, J. D., Chistoserdov, A., Lebron, $131-136$.

Oakley, C. J., and Murrell, J. C. (1991). Cloning of nitrogenase structural genes from the obligate methanotroph Methylococcus capsulatus (Bath). FEMS Microbiol. Lett. 78, 121-126.

Op den Camp, H. J. M., Islam, T., Stott, M. B., Harhangi, H. R., Hynes, A., Schouten, S., Jetten, M. S. M., Birkeland, N. K., Pol, A., and Dunfield, P. F. (2009). Environmental, genomic and taxonomic perspectives on methanotrophic Verrucomicrobia. Environ. Microbiol. Rep. 1, 293-306.

Pieja, A. J., Rostkowski, K. H., and Criddle, C. S. (2011). Distribution and selection of poly-3hydroxybutyrate production capacity in methanotrophic proteobacteria. Microb. Ecol. 62, 564-573.

Pol, A., Heijmans, K., Harhangi, H. R., Tedesco, D., Jetten, M. S. M., and Op den Camp, H. J. M. (2007). Methanotrophy below $\mathrm{pH} 1$ by a new Verrucomicrobia species. Nature 450, 874-879.

Raghoebarsing, A. A., Pol, A., van de Pas-Schoonen, K. T., Smolders, A. J. P., Ettwig, K. F., Rijpstra, W. I. C., Schouten, S., Damste, J. S. S., Op den Camp, H. J. M., Jetten, M. S. M., and Strous, M. (2006). A microbial consortium couples anaerobic methane oxidation to denitrification. Nature 440, 918-921.

Robson, R. L., and Postgate, J. R. (1980). Oxygen and hydrogen in biological nitrogen fixation. Annu. Rev. Microbiol. 34, 183-207. J., Costello, A., Davagnino, J., Kenna, E., Holmes, A. J., Finch, R., Murrell, J. C., and Lidstrom, M. E. (1995). Particulate methane monooxygenase genes in methanotrophs. J. Bacteriol. 177, 3071-3079.

Semrau, J. D., DiSpirito, A. A., and Vuilleumier, S. (2011). Facultative methanotrophy: false leads, true results, and suggestions for future research. FEMS Microbiol. Lett. 323, $1-12$.

Stein, L. Y., and Klotz, M. G. (2011). Nitrifying and denitrifying pathways of methanotrophic bacteria. Biochem. Soc. Trans. 39, 1826-1831.

Stolyar, S., Costello, A. M., Peeples, T. L., and Lidstrom, M. E. (1999). Role of multiple gene copies in particulate methane monooxygenase activity in the methane-oxidizing bacterium Methylococcus capsulatus Bath. Microbiology 145, 1235-1244.

Takeda, K. (1988). Characteristics of a nitrogen fixing methanotroph, Methylocystis T-1. Antonie Van Leeuwenhoek 54, 521-534.

Tavormina, P. L., Orphan, V. J., Kalyuzhnaya, M. G., Jetten, M. S. M., and Klotz, M. G. (2011). A novel family of functional operons encoding methane/ammonia monooxygenase-related proteins in gammaproteobacterial methanotrophs. Environ. Microbiol. Rep. 3, 91-100.

Taylor, S., Ninjoor, V., Dowd, D. M., and Tappel, A. L. (1974). Cathepsin b2 measurement by sensitive fluorometric ammonia analysis. Anal. Biochem. 60, 153-162. van Passel, M. W. J., Kant, R., Zoetendal, E. G., Plugge, C. M., Derrien, M., Malfatti, S. A., Chain, P. S. G., Woyke, T., Palva, A., de Vos, W. M., and Smidt, H. (2011). The genome of Akkermansia muciniphila, a dedicated intestinal mucin degrader, and its use in exploring intestinal metagenomes. PLoS ONE 6, e16876. doi:10.1371/journal.pone.0016876

Wagner, M., and Horn, M. (2006). The Planctomycetes, Verrucomicrobia, Chlamydiae and sister phyla comprise a superphylum with biotechnological and medical relevance. Curr. Opin. Biotechnol. 17, 241-249.

Wang, Z., Gerstein, M., and Snyder, M. (2009). RNA-Seq: a revolutionary tool for transcriptomics. Nat. Rev. Genet. 10, 57-63.

Wanner, U., and Egli, T. (1990). Dynamics of microbial-growth and cell composition in batch culture. FEMS Microbiol. Rev. 75 19-44.

Ward, N., Larsen, O., Sakwa, J., Bruseth, L., Khouri, H., Durkin, A. S., Dimitrov, G., Jiang, L. X., Scanlan, D., Kang, K. H., Lewis, M., Nelson, K. E., Methe, B., Wu, M., Heidelberg, J. F., Paulsen, I. T., Fouts, D. Ravel, J., Tettelin, H., Ren, Q. H., Read, T., DeBoy, R. T., Seshadri, R. Salzberg, S. L., Jensen, H. B., Birkeland, N. K., Nelson, W. C., Dodson, R. J., Grindhaug, S. H., Holt, I., Eidhammer, I., Jonasen, I., Vanaken, S., Utterback, T., Feldblyum, T. V., Fraser, C. M., Lillehaug, J. R., and Eisen, J. A. (2004). Genomic insights into methanotrophy: the complete genome sequence of Methylococcus capsulatus (Bath). PLoS Biol. 2, e303. doi:10.1371/journal.pbio. 0020303

Yimga, M. T., Dunfield, P. F., Ricke, P., Heyer, J., and Liesack, W. (2003). Wide distribution of a novel pmoA-like gene copy among type II methanotrophs, and its expression in Methylocystis strain SC2. Appl. Environ. Microbiol. 69, 5593-5602.

Conflict of Interest Statement: The authors declare that the research was conducted in the absence of any commercial or financial relationships that could be construed as a potential conflict of interest.

Received: 23 May 2012; accepted: 05 July 2012; published online: 25 July 2012.

Citation: Khadem AF, Pol A, Wieczorek $A S$, Jetten MSM and Op den Camp HJM (2012) Metabolic regulation of "Ca. Methylacidiphilum fumariolicum" SolV cells grown under different nitrogen and oxygen limitations. Front. Microbio. 3:266. doi: 10.3389/fmicb.2012.00266

This article was submitted to Frontiers in Evolutionary and Genomic Microbiology, a specialty of Frontiers in Microbiology. Copyright (c) 2012 Khadem, Pol, Wieczorek, Jetten and Op den Camp. This is an open-access article distributed under the terms of the Creative Commons Attribution License, which permits use, distribution and reproduction in other forums, provided the original authors and source are credited and subject to any copyright notices concerning any third-party graphics etc. 


\section{APPENDIX}

Table A1 | Transcription of genes involved in carbon fixation and the pentose phosphate pathway in "Ca. M. fumariolicum" strain SolV.



The mRNA expression is expressed as RPKM according to Mortazavi et al. (2008). Changes in expression in the chemostat cultures ( $\mathrm{N}_{2}$ fixing cells or $\mathrm{O}_{2}$ limited cells) compared to batch culture cells growing at $\mu_{\max }$ are indicated by shading: up regulation $>2$ times (dark gray), down regulation $<0.5$ (light gray). 
Table A2 | Transcription of genes involved the TCA cycle in "Ca. M. fumariolicum" strain SolV.

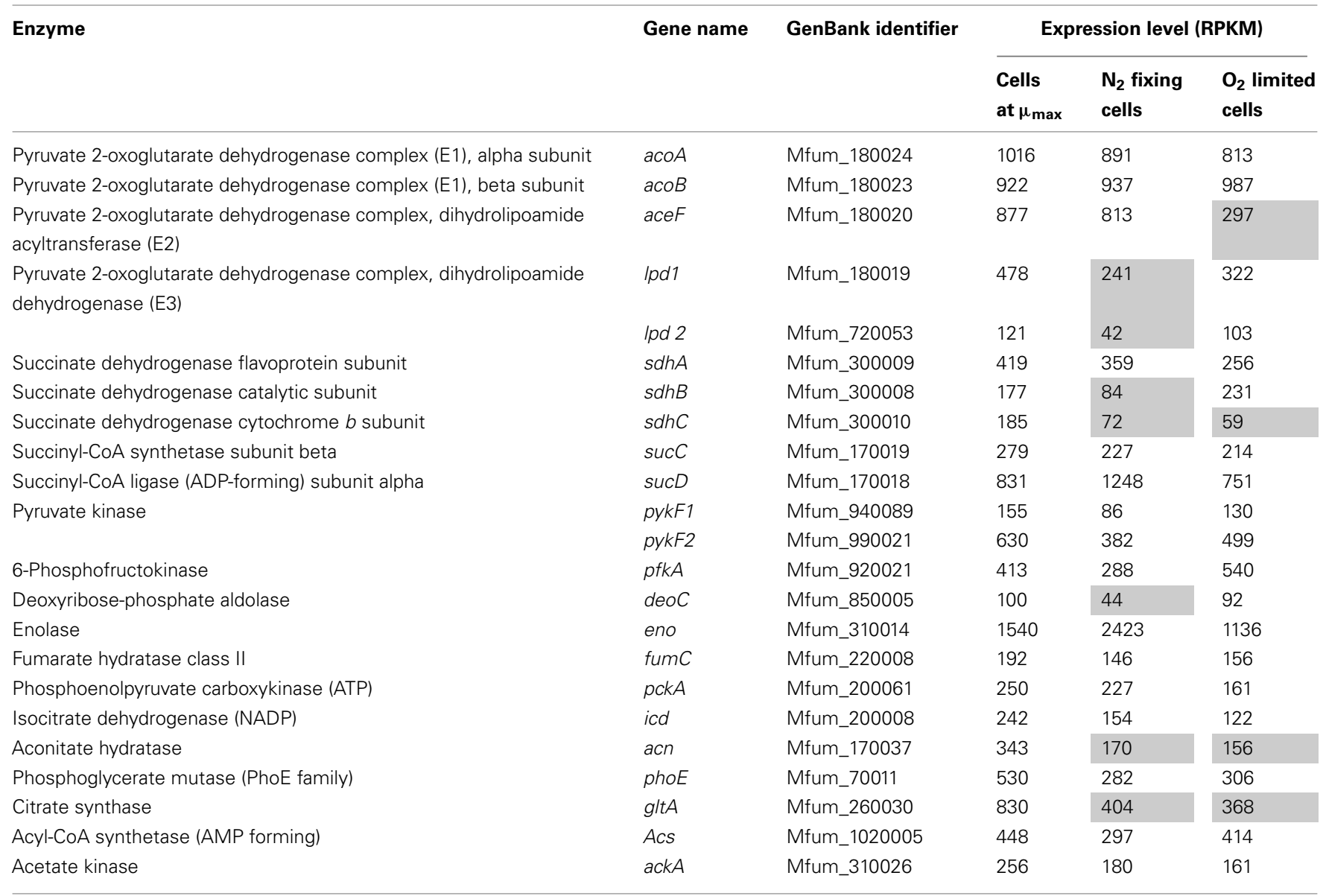

The mRNA expression is expressed as RPKM according to Mortazavi et al. (2008). Changes in expression in the chemostat cultures $\left(\mathrm{N}_{2}\right.$ fixing cells or $\mathrm{O}_{2}$ limited cells) compared to batch culture cells growing at $\mu_{\max }$ are indicated by shading: up regulation $>2$ times (dark gray), down regulation $<0.5$ (light gray). 
Table A3 | Transcription of genes involved carbon and energy storage in "Ca. M. fumariolicum" strain SolV.

\begin{tabular}{|c|c|c|c|c|c|}
\hline \multirow[t]{2}{*}{ Enzyme } & \multirow[t]{2}{*}{ Gene name } & \multirow[t]{2}{*}{ GenBank identifier } & \multicolumn{3}{|c|}{ Expression level (RPKM) } \\
\hline & & & $\begin{array}{l}\text { Cells } \\
\text { at } \mu_{\max }\end{array}$ & $\begin{array}{l}\mathrm{N}_{2} \text { fixing } \\
\text { cells }\end{array}$ & $\begin{array}{l}\mathrm{O}_{2} \text { limited } \\
\text { cells }\end{array}$ \\
\hline Glycogen synthase 2 & $g \lg A$ & Mfum_1010040 & 306 & 242 & 346 \\
\hline 1,4-Alpha-glucan-branching enzyme & $g \lg B$ & Mfum_170041 & 154 & 91 & 110 \\
\hline Malto-oligosyltrehalose trehalohydrolase & $g \lg B$ & Mfum_170046 & 162 & 128 & 81 \\
\hline \multirow[t]{3}{*}{ Glucan phosphorylase } & $g \lg P 1$ & Mfum_1020098 & 656 & 447 & 843 \\
\hline & $g \lg P 2$ & Mfum_220010 & 113 & 98 & 122 \\
\hline & $g \lg P 3$ & Mfum_880004 & 447 & 382 & 450 \\
\hline Glycogen operon protein homolog & $g \lg X$ & Mfum_40003 & 381 & 218 & 263 \\
\hline Glycogen debranching enzyme & $g d b$ & Mfum_200059 & 256 & 246 & 106 \\
\hline ABC-type phosphate transport system, permease & pstA & Mfum_300005 & 81 & 45 & 98 \\
\hline \multirow[t]{2}{*}{ Exopolyphosphatase } & gppA1 & Mfum_1010048 & 581 & 430 & 486 \\
\hline & gppA2 & Mfum_1020105 & 101 & 63 & 101 \\
\hline Polyphosphate kinase & ppk & Mfum_1030014 & 266 & 206 & 197 \\
\hline Exopolyphosphatase-related protein & & Mfum_550017 & 506 & 283 & 404 \\
\hline Adenylate kinase & $a d k$ & Mfum_210014 & 247 & 88 & 170 \\
\hline
\end{tabular}

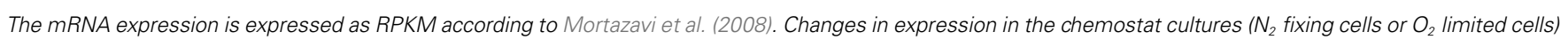
compared to batch culture cells growing at $\mu_{\max }$ are indicated by shading: up regulation $>2$ times (dark gray), down regulation < 0.5 (light gray). 

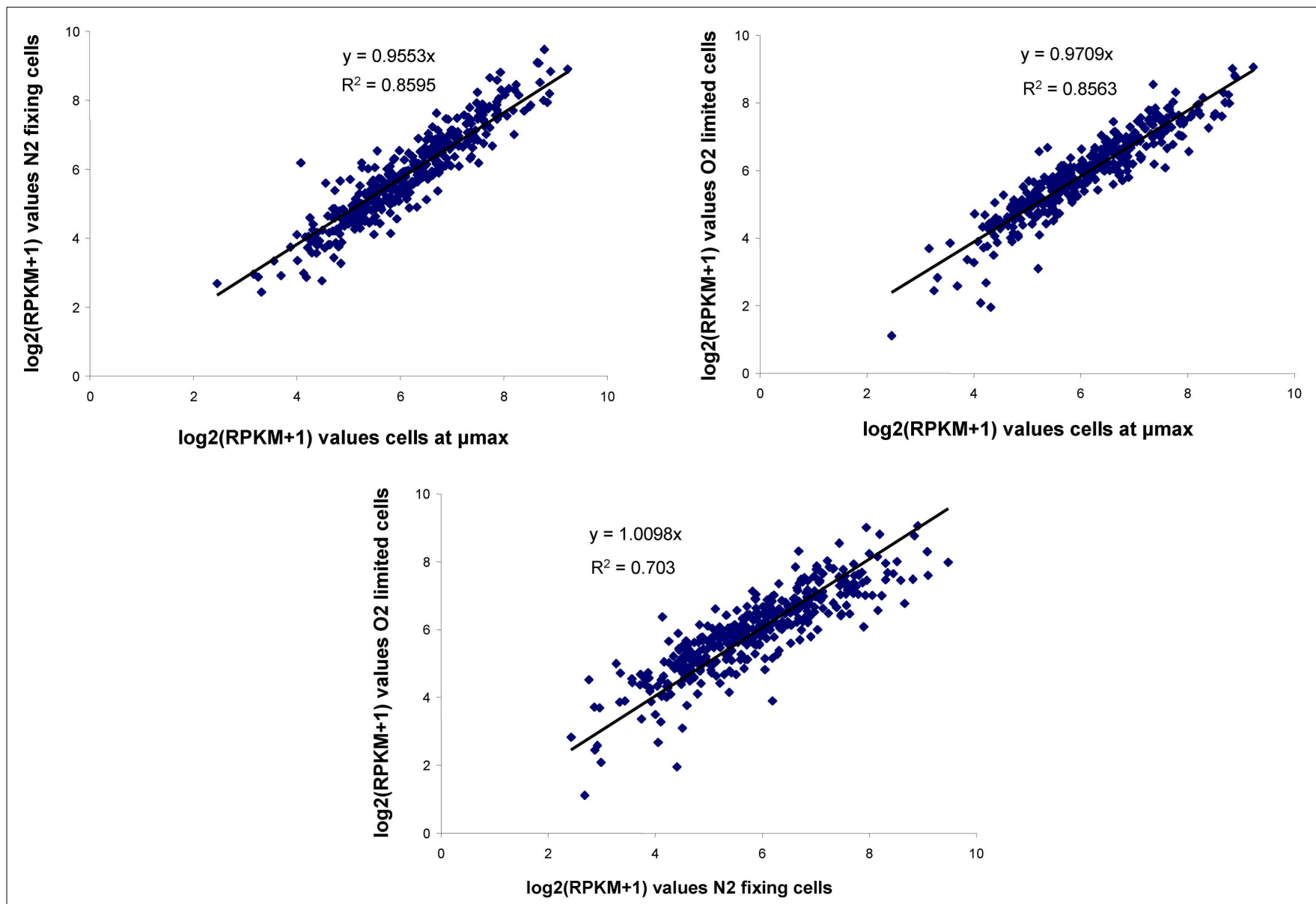

FIGURE A1 | Plots of expression levels (log2(RPKM + 1)) of 394 genes (in total $443 \mathrm{kbp}$ ) involved in energy generation, ribosomes, carbon fixation (CBB cycle), Cl metabolism (except for pmo), amino acid synthesis, cell wall synthesis, translation, transcription, DNA replication, and tRNA synthesis. 